\title{
The needle penetration test for predicting coal strength
}

\author{
by S. Kahraman*, A.S. Aloglu†, B. Aydin*, and E. Saygin*
}

\section{Synopsis}

The coal strength parameter is used in operations such as the selection and design of mechanical excavators and coal crushing/grinding equipment. However, coring or cutting prismatic specimens from coal for the standard strength tests is difficult, and sometimes not possible. For this reason a method for the indirect determination of coal strength from easy tests would be useful. In this study, the predictability of coal strength from the needle penetration test was investigated. This is a very easy and practical test method. Point load and needle penetration index (NPI) tests were carried out on coal specimens from Çayırhan coalfield in Turkey. The point load indexes were converted to the uniaxial compressive strength (UCS) values by using the general conversion factor. The UCS and NPI values were evaluated using regression analysis. A strong linear relationship was found between the two parameters. The conversion factor for the UCS-NPI ratio is 0.35 for the tested coal samples. It is concluded that the UCS of coal can be predicted from the NPI.

Keywords

coal, uniaxial compressive strength, needle penetration index.

\section{Introduction}

Knowledge of coal strength is important for the selection and design of mechanical excavators and coal crushing and grinding equipment. Uniaxial compressive strength of coal is used in designing pillar dimensions in room and pillar mining. Coals always contain bedding planes and cleats; they are also brittle and fragile. Therefore, coring or cutting prismatic specimens from coal for the standard strength tests is difficult, and sometimes not possible. For this reason, a method for the estimation of coal strength from easy tests would be useful.

The needle penetration test is a nondestructive index test that is applicable both in the field and the laboratory and does not require any special sample preparation. The test has been used for the estimation of physical and mechanical properties of weak or soft rocks (Okada et al., 1985; Yamaguchi et al., 1997; Takahashi, Noto, and Yokokawa, 1988; Uchida et al., 2004; Aydan et al., 2006; Aydan, Watanabe, and Tokashiki, 2008; Aydan, 2012; Erguler and Ulusay, 2007; Park, Obara, and Kan, 2011; Ulusay and Erguler, 2012; Aydan and Ulusay, 2013; Aydan. Sato, and Yagi, 2014). This study investigates the predictability of coal strength from the needle penetration test.

\section{Previous studies}

The needle penetration test was originally developed by MARUTO Testing Machine Company (1999) for estimating the uniaxial compressive strength (UCS) of soft rocks. Several researchers have used the needle penetration index (NPI) to estimate the uniaxial compressive strength of rocks (Okada et al., 1985; Yamaguchi et al., 1997; Takahashi, Noto, and Yokokawa, 1988; Uchida et al., 2004; Aydan et al., 2006; Aydan, Watanabe, and Tokashiki, 2008; Aydan, 2012; Erguler and Ulusay, 2007; Park, Obara, and Kan, 2011; Ulusay and Erguler, 2012). Some researchers have also investigated the relations between the NPI and other rock properties such as tensile strength, Young's modulus (Aydan, 2012; Aydan and Ulusay, 2013; Aydan, Sato, and Yagi, 2014), and P- and S-wave velocities (Aydan, 2012; Aydan, Sato, and Yagi, 2014), cohesion, and friction angle (Aydan, Sato, and Yagi, 2014).

Ulusay and Erguler (2012) evaluated a database consisting of a total of 725 UCS-NPI data pairs from previous studies and additional tests and suggested the following relationship between UCS and NPI:

$$
\mathrm{UCS}=0.4 \mathrm{NPI}^{0.929}
$$

where the UCS is measured in megapascals and the NPI in newtons per millimetre.

Although Equation [1] is not linear, Aydan (2012) found the following linear relationship for different rock types such as tuff, sandstone, pumice, limestone, and lignite measures (lignite, mudstone, siltstone, marl, loam):

\section{$\mathrm{UCS}=0.2 \mathrm{NPI}$}

Aydan (2012) also stated that the conversion factor for the UCS-NPI relation

\footnotetext{
* Mining Engineering Department, Hacettepe University, Ankara, Turkey.

+ CINER Group, Ankara, Turkey.

(c) The Southern African Institute of Mining and Metallurgy, 2017. ISSN 2225-6253. Paper received June 2016; revised paper received Sept. 2016.
} 


\section{The needle penetration test for predicting coal strength}

ranges between 0.06 and 0.7 , and the relationship should be evaluated individually for each rock group to improve the correlations.

Recently, Aydan and Ulusay (2013) derived the following relation for Derinkuyu tuff:

$$
\mathrm{UCS}=0.3 \mathrm{NPI}
$$

\section{Geology and sampling}

Coal samples were provided from the Çayırhan underground lignite mine located in Çayırhan Town of Nallihan County, $122 \mathrm{~km}$ west of Ankara, Turkey (Figure 1).

The Cayirhan coal basin comprises a Miocene series termed M1, M2, M3, and M4 and Pliocene formation (Figure 2). Coal seams are located in the M1 formation, which is some four kilometers wide and approximately $25 \mathrm{~km}$ long, elongated in a southwest to northeast direction (Haciosmanoglu, 2004). There are two lignite seams - seams 1 and 2 - in the basin, which vary in thickness from 1.7 to $2.0 \mathrm{~m}$. The two seams are separated by an interburden with a thickness of $1.3-2.0 \mathrm{~m}$ in the western part of the area and 0.5-0.7 $\mathrm{m}$ on the eastern side (Aydin and Kaygusuz, 2001).

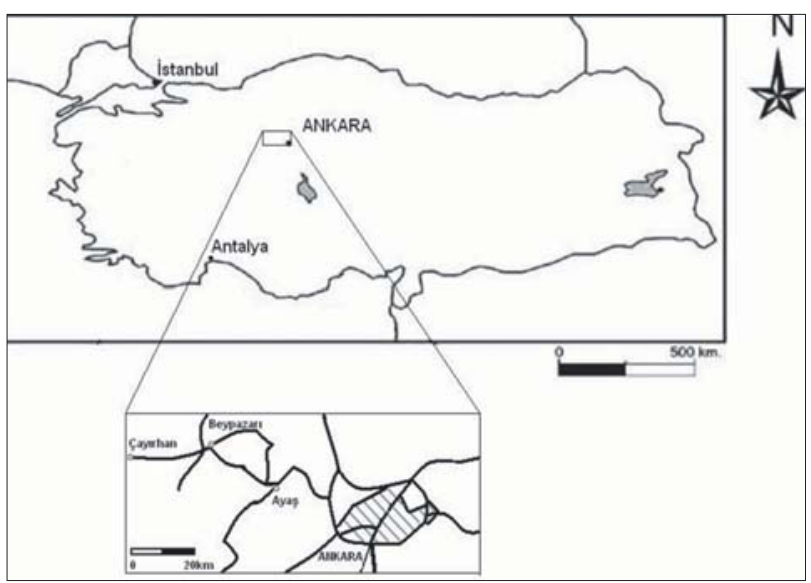

Figure 1-Location of Çayırhan coal mine

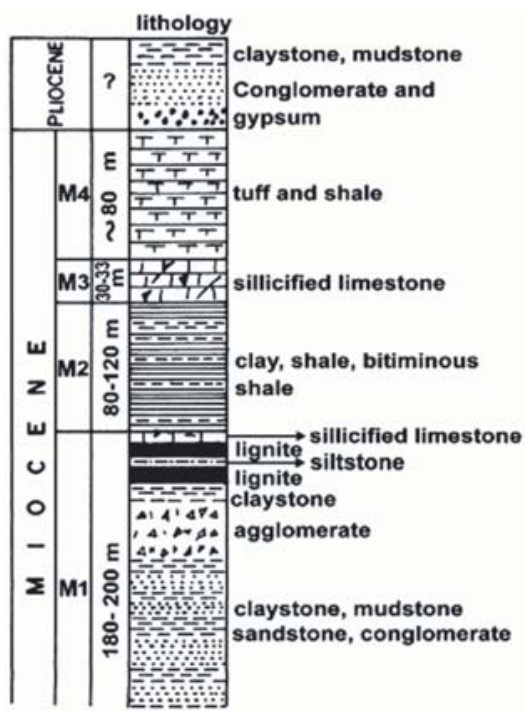

Figure 2-Vertical cross-section of the Cayirhan coal basin (Aydin and Funfstuck, 1988)
The dry ash-free carbon content of the coals varies between $61 \%$ and $80 \%$, which is a very large range, from lignite to high-volatile $\mathrm{C}$ bituminous coal rank. The average bed moisture of the samples was $24.3 \%$, which puts them in the sub-bituminous coal rank. The major inorganic mineral phases found in the raw coal are clinoptilolite, analcime, and pyrite, with variable minor amounts of quartz, albiteanorthite, gypsum, marcasite, illite, dolomite, and apatite (Whateley et al., 1996).

Several researchers have carried out mechanical and physical tests on Cayirhan coal. Their results are summarized in Table I.

The mine was visited and the block samples of coals were collected from the ten different locations (Table II, Figure 3) and transported to the laboratory for testing.

\begin{tabular}{|c|c|c|c|c|c|c|}
\hline \multicolumn{7}{|c|}{$\begin{array}{l}\text { Table I } \\
\text { Mechanical and physical properties of Çayirhan } \\
\text { coal }\end{array}$} \\
\hline \multicolumn{2}{|c|}{ UCS (MPa) } & \multicolumn{2}{|c|}{$\begin{array}{c}\text { Tensile } \\
\text { strength }(\mathrm{MPa})\end{array}$} & \multicolumn{2}{|c|}{ Density $\left(\mathrm{g} / \mathrm{cm}^{3}\right)$} & \multirow[t]{2}{*}{ Source } \\
\hline $\begin{array}{l}\text { Lower } \\
\text { coal bed }\end{array}$ & $\begin{array}{c}\text { Upper } \\
\text { coal bed }\end{array}$ & $\begin{array}{l}\text { Lower } \\
\text { coal bed }\end{array}$ & $\begin{array}{l}\text { Upper } \\
\text { coal bed }\end{array}$ & $\begin{array}{l}\text { Lower } \\
\text { coal bed }\end{array}$ & $\begin{array}{c}\text { Upper } \\
\text { coal bed }\end{array}$ & \\
\hline 8.6 & 7.9 & 2.10 & 2.60 & --- & --- & $\begin{array}{l}\text { Tiryaki et } \\
\text { al. (2001) }\end{array}$ \\
\hline$\overline{10.2}$ & 7.1 & 2.15 & 1.94 & 1.53 & 1.53 & Keles, 2005 \\
\hline 12.1 & 10.8 & 1.29 & 1.07 & 1.38 & 1.37 & Bilim, 2007 \\
\hline
\end{tabular}

Table II

Sampling locations

\begin{tabular}{l|c|c|} 
Code & Sampling location & Sampling point \\
\hline 1 & Roadway D210/3 & 316th metre \\
2 & Roadway D210 & 136.5th metre \\
3 & Roadway D210 & 136.5th metre \\
4 & Roadway D210/2 & 321st metre \\
5 & Access gallery D210 & 300th metre \\
6 & Ventilation gallery D & 1111.75 th metre \\
7 & Roadway G 510 & 1542 nd metre \\
8 & Roadway G 510 & 1551 st metre \\
9 & Ventilation gallery D & 1106.75 th metre \\
10 & Ventilation gallery D & 112.75 th metre \\
& &
\end{tabular}

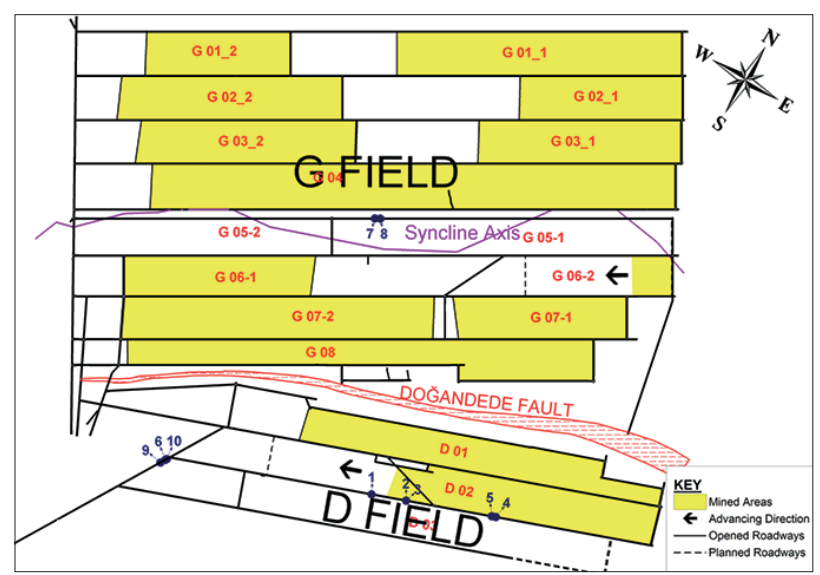

Figure 3-Mine plan showing the sampling locations 


\section{The needle penetration test for predicting coal strength}

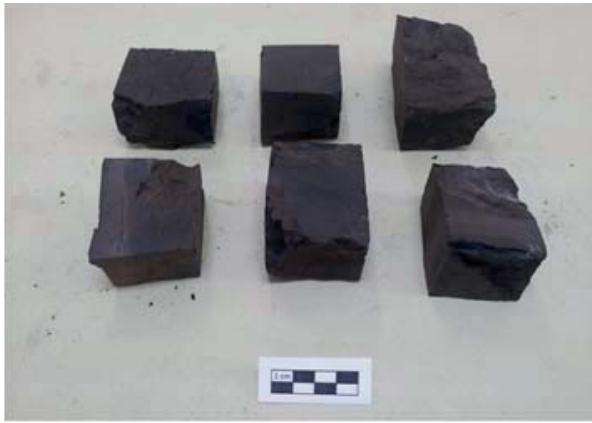

Figure 4-Some of the test specimens used in the point load tests

\section{Point load test}

Since the coal samples were weak, intact samples could not be prepared for the uniaxial compressive strength test. For this reason point load testing was selected for the strength test. About 70 prismatic test specimens were prepared from the coal blocks by diamond sawing (Figure 4). However, only 46 test results were accepted due to invalid failure modes observed in numerous specimens during testing due to the brittle nature of coal.

After calculating point load index values, the results were corrected to a specimen diameter of $50 \mathrm{~mm}$. Franklin (1985) suggests that the ratio between the UCS and point load index is approximately 22 for different rock types. Therefore, point load index values were multiplied by 22 and converted to the UCS values.

\section{Needle penetration test}

The needle penetrometer was developed by MARUTO Co. in Japan to estimate the UCS of soft rocks. It is a lightweight portable device with a weight of about $700 \mathrm{~g}$. The needle is a hardened steel, $0.84 \mathrm{~mm}$ diameter rod with a conical tip. The major components of the device are a plunger, chuck, penetration scale $(0-10 \mathrm{~mm}$ in $1 \mathrm{~mm}$ graduations), load scale (0-100 N in $10 \mathrm{~N}$ graduations), load indicator ring, cap (removable; spare penetration needles contained in the grip), penetration needle, and spring mounted in the penetrometer grip as shown Figure 5.

The needle of the penetrometer is pushed into the rock until a force of $100 \mathrm{~N}$ is reached and the penetration depth is measured from the position of the plunger on the penetration scale. The maximum penetration depth $(10 \mathrm{~mm})$ may be attained for softer and saturated rocks before the maximum penetration force is reached. In this case, the test stops at this depth, the penetration load is read from the load scale, and the NPI is calculated from the following equations:

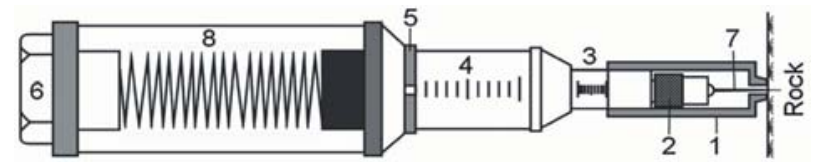

Figure 5 - The needle penetrometer. (1) plunger, (2 ) chuck, (3) penetration scale, (4) load scale, (5) load indicating ring, (6) cap, (7) penetration needle, and (8) spring (Tiryaki et al., 2001)

$$
\begin{array}{ll}
\text { For } F=100 \mathrm{~N} \text { and } D \leq 10 \mathrm{~mm} & \mathrm{NPI}=100 / D \\
\text { For } D=10 \mathrm{~mm} \text { and } F \leq 100 \mathrm{~N} & \mathrm{NPI}=F / 10
\end{array}
$$

where NPI is the needle penetration index $(\mathrm{N} / \mathrm{mm}), F$ is the applied load $(\mathrm{N})$, and $D$ is the depth of penetration $(\mathrm{mm})$ (Ulusay et al., 2014).

The needle penetration tests were carried out on the coal samples that failed in the point load tests (Figure 6). The tests were carried out on the top and bottom surfaces of the specimens at least four times and the results averaged to pair up with the corresponding UCS values for that particular specimen.

\section{Results and discussion}

The descriptive statistics of the test results are listed in Table III. The skewness values of each test are also given. In

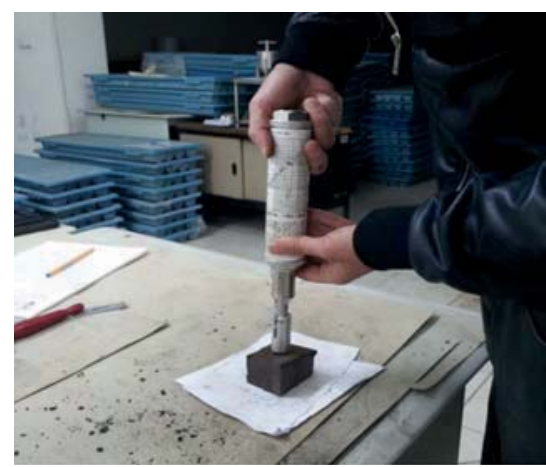

Figure 6-The needle penetration test

\section{Table III \\ Descriptive statistics of the test results}

\begin{tabular}{|l|c|c|}
\hline $\begin{array}{l}\text { Statistical } \\
\text { parameter }\end{array}$ & UCS (MPa) & NPI (N/mm) \\
\hline Number of data & 46 & 184 \\
Minimum value & 1.00 & 1.00 \\
Maximum value & 16.04 & 51.30 \\
Average value & 6.59 & 18.18 \\
Standard deviation & \pm 3.64 & \pm 12.69 \\
Skewness & 0.45 & 1.19 \\
\hline
\end{tabular}

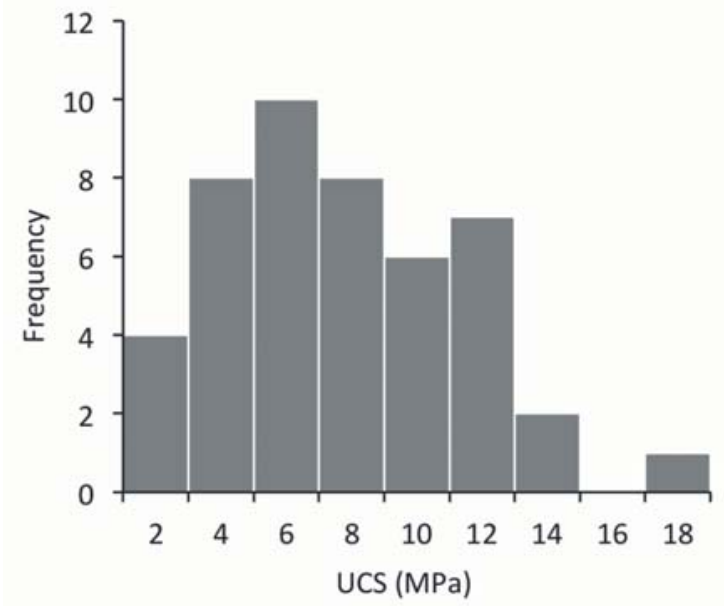

Figure 7-Histogram plot for the UCS data 


\section{The needle penetration test for predicting coal strength}

addition, histogram plots of the UCS and NPI values are presented (Figures 7 and 8). The skewness values and histogram plots indicate that the data for UCS and NPI show fairly normal distributions.

The UCS and average NPI values were analysed using the method of least-squares regression. Linear approximation was executed to check the correlation between the UCS and NPI, as shown in Figure 9. The UCS increases with increasing NPI. The equation and the correlation coefficient of the relation ( $\mathrm{r}$ ) are:

$\mathrm{UCS}=0.35 \mathrm{NPI}$

$$
r=0.81
$$

Although the data points are a bit scattered, the correlation coefficient is high enough for the estimation purposes. The scattering is probably due to the brittle nature of the coal.

Aydan (2012) showed that the conversion factor for the UCS-NPI relationship ranged between 0.06 and 0.7 and most of the data points were concentrated around the regression line with a slope of 0.2. In this study, the conversion factor of 0.35 (Equation [6]) falls in the range defined by Aydan (2012). In order to make a comparison, Equations [1]-[3] and [6] were plotted (Figure 10). Equation [6] indicates almost the same trend as the models derived by Ulusay and

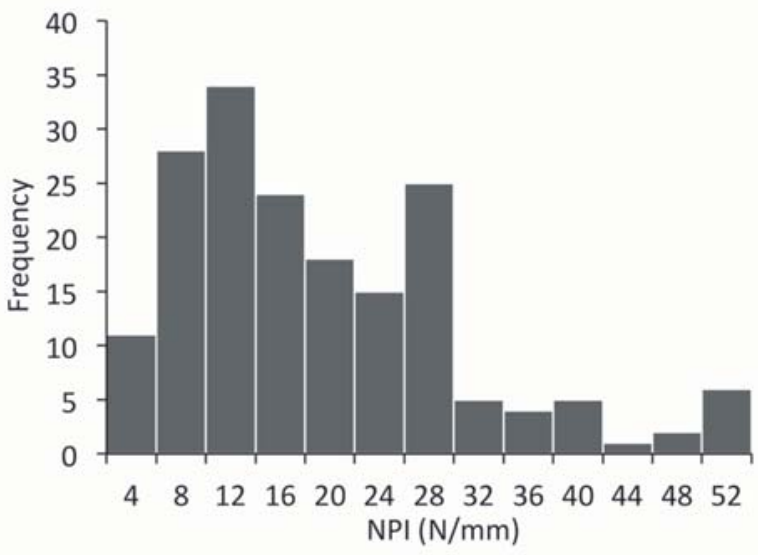

Figure 8-Histogram plot for the NPI data

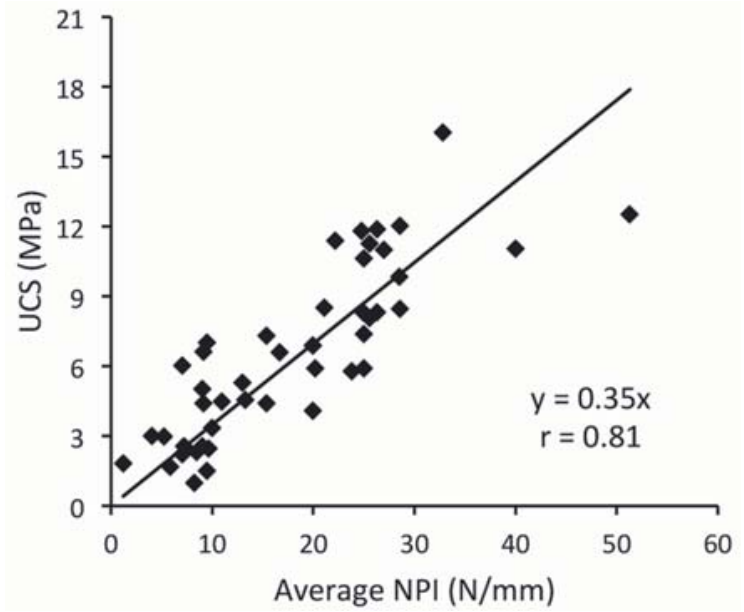

Figure 9-Correlation between the UCS and NPI for Cayirhan coal
Erguler (2012) and Aydan and Ulusay (2013). There is a small difference between Equation [6] and the model derived by Aydan (2012). The derivation of a general equation for all rock types is difficult. Aydan (2012) stated that the conversion factor for the UCS-NPI relationship should be evaluated for each rock group separately in order to improve the correlations.

The correlation coefficient of the derived equation is good, but this does not necessarily identify a valid model. For this reason, the validation of the relationship was checked by the $t$-test and the $F$-test.

The significance of $r$ values can be determined by the $t$ test, assuming that both variables are normally distributed and observations are chosen randomly. The test compares the computed $t$-value with the tabulated $t$-value using the null hypothesis. In this test, a 95\% level of confidence was chosen. If the computed $t$-value is greater than tabulated $t$ value, the null hypothesis is rejected. This means that $r$ is significant. If the computed $t$-value is less than tabulated $t$ value, the null hypothesis is not rejected. In this case, $r$ is not significant. As seen in Table III, the computed $t$-value is greater than tabulated $t$-value. Therefore, it can be said that the derived equation is valid according to the $t$-test.

The significance of regressions was determined by the analysis of variance. In this test, a 95\% level of confidence was chosen. If the computed $F$-value is greater than tabulated $F$-value, the null hypothesis is rejected, and there is a real relationship between the dependent and independent variables. The computed $F$-value is greater than the tabulated $F$-value, as shown in Table IV. Therefore, it is concluded that the derived equation is valid according to the $F$-test

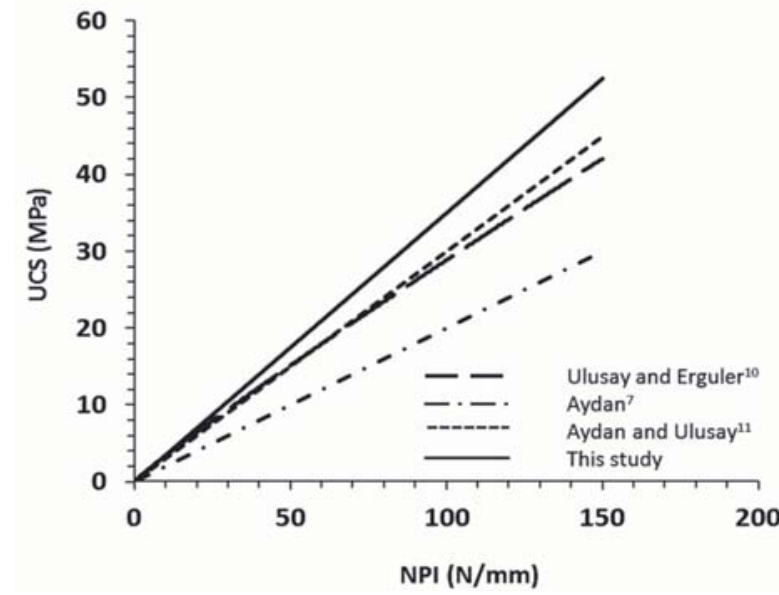

Figure 10-Comparison of conversion factors for the UCS-NPI relation this study (Equation [6]) and the previous models

\begin{tabular}{|c|c|c|c|}
\hline \multicolumn{4}{|c|}{ Table IV } \\
\hline \multicolumn{4}{|c|}{$t$ - and $F$-test results for Equation [6] } \\
\hline $\begin{array}{l}t \text {-table } \\
\pm 2.01\end{array}$ & $\begin{array}{l}t \text {-test } \\
10.13\end{array}$ & $\begin{array}{c}F \text {-table } \\
3.94\end{array}$ & $\begin{array}{l}F \text {-test } \\
49.19\end{array}$ \\
\hline
\end{tabular}




\section{The needle penetration test for predicting coal strength}

\section{Conclusions}

Point load and the needle penetration index tests were carried out on Çayirhan coal specimens in the laboratory in order to investigate the predictability of coal strength from the needle penetration index.

The regression analysis indicated that there is a linear relationship between uniaxial compressive strength and the needle penetration index, and the correlation coefficient is high. The statistical tests also show that the derived relationship is significant. The derived correlation shows a similar trend to those found in the literature. It is concluded that the strength of Çayirhan coal can be predicted easily from the needle penetration index by using the derived correlation. Further research is necessary to check if the derived equation is valid for other coal types.

\section{Acknowledgement}

The authors thank TUBITAK (the Scientific and Technological Research Council of Turkey) for the support of the project (Project No. 114M836). We also thank the CINER Group for providing samples.

\section{References}

Aydan, O. 2012. The inference of physico-mechanical properties of soft rocks and the evaluation of the effect of water content and weathering on their mechanical properties from needle penetration tests. Proceedings of the 46th US Rock Mechanics and Geomechanics Symposium, Chicago, IL, 2427 June 2012. Paper no. ARMA12- 639. American Rock Mechanics Association, Alexandria, VA. [on CD].

Aydan, O. and Ulusay, R. 2013. Geomechanical evaluation of Derinkuyu antique underground city and its implications in geoengineering. Rock Mechanics and Rock Engineering, vol. 46. pp. 731-754.

Aydan, O., Seiki, T., Ito, T., Ulusay, R., and Yuzer, E. 2006. A comparative study on engineering properties of tuffs from Cappadocia of Turkey and Oya of Japan. Proceedings of the Symposium on Modern Applications of Engineering Geology. Turkish National Group of Engineering Geology, Denizli, Turkey. pp. 425-433.

Aydan, O., WATANABE, S., and TокаSнікі, N. 2008. The inference of mechanical properties of rocks from penetration tests. Proceedings of the 5th Asian Rock Mechanics Symposium (ARMS5), Tehran, Iran, 24-26 November 2008. International Society for Rock Mechanics, Lisbon, Portugal. Vol 1. pp. 213-220.

Aydan. O., SATo, A., and YAgi, M. 2014. The inference of geo-mechanical properties of soft rocks and their degradation from needle penetration tests. Rock Mechanics and Rock Engineering, vol. 47. pp. 1867-1890.

Aydin, Y. and Funfstuck 1988. Beypazari Project report. Proceedings of the Sixth Coal Congress of Turkey. Chamber of Mining Engineers of Turkey, Ankara. pp. 53-71 (in Turkish).

Aydin, Y. and Kaygusuz, Y. 2001. Evaluation of single-slice and twin-face operations of Cayirhan lignite seams. Proceedings of the 17th International Mining Congress and Exhibition of Turkey (IMCET 2001), Ankara, Turkey, 19-22 June 2001. Chamber of Mining Engineers of Turkey, Ankara. pp. 567-573.

BıLıм, N. 2007. Çayırhan yeraltı kömür oca ında kazı makinalarının performanslarının ara tırılması ve kayaç özellikleri ile ili kilendirilmesi. [Investigation of the performance of excavators in Çayirhan underground coal mine as related to rock properties] $\mathrm{PhD}$ thesis, Selcuk University, Konya, Turkey. 270 pp. (In Turkish).

ERGULER, Z.A. and ULUSAY, R. 2007. Estimation of uniaxial compressive strength of clay-bearing weak rocks using needle penetration response. Proceedings of the 11th Congress of the International Society of Rock Mechanics, Lisbon, Portugal. Vol 1. pp. 265-268.

FRANKLIN, J.A. 1985. Suggested method for determining point load strength. International Journal of Rock Mechanics and Mining Sciences \& Geomechanics Abstracts, vol. 22, no. 2. pp. 51-60.

Haciosmanoglu, M.E. 2004. Development of a subsidence model for Cayirhan coal mine. MSc thesis. Middle East Technical University, Ankara, Turkey. $154 \mathrm{pp}$

KeLES, S. 2005. Cutting performance assessment of a medium weight roadheader at Cayirhan coal mine. MSc thesis, Middle East Technical University, Ankara, Turkey. 58 pp.

Maruto Testing Machine Company. 1999. Instructions for SH-70 Penetrometer (NANGAN-PENETOROKEI). Tokyo, 4 pp. (in Japanese).

ОКАDA, S., IZUMIYA, Y., IIZUKA, Y., and HoRIUchI, S. 1985. The estimation of soft rock strength around a tunnel by needle penetration test. Journal of the Japanese Society of Soil Mechanics and Foundation Engineering, vol. 33 no. 2. pp. 35-38. (In Japanese).

PARK, Y., OBARA, Y., and KAn, S.S. 2011. Estimation of uniaxial compressive strength of weak rocks using needle penetrometer. Proceedings of the 12th ISRM International Congress on Rock Mechanics, Beijing, 18-21 October 2011. International Society for Rock Mechanics, Lisbon, Portugal. pp. 795-798.

TAKАнАSHI, K., Nото, K., and ҮококаWА, I. 1988. Strength characteristics of Kobe formation in Akashi Strata (No. 1). Proceedings of 10th Japan National Conference on Geotechnical Engineering. Japanese Geotechnical Society. pp. 1231-1232. (In Japanese).

Tiryaki, B., Atasoy, K., Yasitli, N.E., Eyuboglu, A.S., and Aydin, M.Z. 2001. Studies in the relationships between hardgrove grindability and some rock index tests on Cayirhan coals. Proceedings of the 17th International Mining Congress and Exhibition of Turkey (IMCET 2001), Ankara, Turkey, 19-22 June 2001. Chamber of Mining Engineers of Turkey. pp. 451-458.

UchidA, N., Етон, Y., ONo, H., and MiURA, N. 2004. Strength evaluation of deep mixing soil-cement by needle penetration test. Journal of the Japanese Society of. Soil Mechanics and Foundation Engineering, vol. 52, no. 7. pp. 23-25. (In Japanese).

UluSAY, R. and ERGuLER, Z.A. 2012. Needle penetration test: evaluation of its performance and possible uses in predicting strength of weak and soft rocks. Engineering Geology, vol. 149-150. pp. 47-56.

Ulusay, R., Aydan, O., Erguler, Z.A., Ngan-Tillard, D.J.M., Seiki, T., Verwaal, W., SASAKI, Y., and SATO, A. 2014. ISRM suggested method for the needle penetration test. Rock Mechanics and Rock Engineering, vol. 47. pp. $1073-1085$

Whateley, M.K.G., Querol, X., Fernandez-Turiel. J.L., and Tuncali, E. 1996. Zeolites in Tertiary coal from the Cayirhan mine, Beypazari, Turkey. Mineralium Deposita, vol. 31. pp. 529-538.

YAmAguchi, Y., OGAWA, N., KAWASAKI, M., and NAKAMURA, A. 1997. Evaluation of seepage failure response potential of dam foundation with simplified tests. Journal of the Japanese Society of Engineering Geology, vol. 38, no. 3. pp. 130-144. 